https://helda.helsinki.fi

Human Rights in Interwar Finland

\author{
Elmgren, Ainur
}

2018-10-30

Elmgren, A 2018 , ' Human Rights in Interwar Finland ', Nordic journal of human rights , vol. 36 , no. 3 , pp. 219-236 . https://doi.org/10.1080/18918131.2018.1522760

http://hdl.handle.net/10138/314500

https://doi.org/10.1080/18918131.2018.1522760

unspecified

acceptedVersion

Downloaded from Helda, University of Helsinki institutional repository.

This is an electronic reprint of the original article.

This reprint may differ from the original in pagination and typographic detail.

Please cite the original version. 
Human Rights in Interwar Finland

Ainur Elmgren

Department of Philosophy, History and Art Studies, University of Helsinki, Helsinki, Finland

PL 59 (Unioninkatu 38), FI-00014 University of Helsinki, Finland

Tel. +358 (0)2941 23749

E-mail: ainur.elmgren@helsinki.fi

Abstract:

In the 1930s, activists fought for the protection of civil rights in the Republic of Finland, expanding the notion of rights to include also categories of people who had been previously excluded, such as political prisoners, the mentally ill, and foreign refugees. Two of these activists were the editor of the journal Tulenkantajat, Erkki Vala, and the chair of the League of Human Rights in Finland, Väinö Lassila. Their usage of the concept 'human rights', drawing from the traditions of liberal humanism, Christian anarchism and the socialist labour movement, is analysed in the national and international context of the interwar era. During the 1930s, Erkki Vala increasingly used the concept 'human rights' in ways that seem to predate the so-called starting point of modern human rights discourse in the 1940s. He met with compact resistance from the authorities, which contributed to his political marginalization and radicalisation. This article shows that the notion of universal human rights was not unthinkable before the end of the Second World War, but it was heavily politicised and controversial even in a democratic country such as the Republic of Finland.

Keywords: human rights, civil rights, Finland, human rights leagues, intellectuals

\section{Human Rights in Interwar Finland}

Between the years 1932 and 1939, journalist and editor Erkki Vala (1902-1991) waged a battle for the protection of civil rights in the Republic of Finland. Through his journal Tulenkantajat and his activism in the League of Human Rights in Finland, Vala collected a multitude of civil rights grievances under the internationalist umbrella of anti-fascism, which gained him an access to open as well as clandestine support networks, but also made him vulnerable to public attacks from conservative nationalists. In this struggle, Vala used the concept 'human rights' in ways that seem to predate what is usually described as the starting point of modern human rights discourse in the 1940s. 
This case study is a contribution to the conceptual history of human rights in the interwar era. Previous studies on the topic have noted different situational uses of the concept before the international phenomenon of an expansion of the human rights discourse after 1945, but there have been few attempts at constructing a genealogy of the concept until that revolutionary moment. ${ }^{1}$ Scholars in the field may take for granted established narratives of the history of human rights, for example that only in the second half of the twentieth century "did human rights develop into a political and legal vocabulary for confronting abuses of disciplinary state power". ${ }^{2}$ As Samuel Moyn summarizes Hannah Arendt on rights in The Origins of Totalitarianism, "there is a clear and fundamental difference between earlier rights, all predicated on belonging to a political community, and eventual 'human rights". ${ }^{3}$ My intention is not to contradict these statements but to nuance them, to explore "the emergence of a local ideology of rights" through "the changing contexts and expectations of the subjects who invoke them", and in this process uncover predecessors of the modern notion of universal human rights. ${ }^{4}$ Why did these voices remain unheeded, and what drove them in the pursuit to transcend the limitations of the nation state despite overwhelming resistance from legal and political authorities?

Samuel Moyn appeals to a conceptual difference between rights of man and human rights - the latter first appearing in English as an 'accidental variation' by Thomas Paine of his translation of droits de l'homme which did not catch on until the 1940s. ${ }^{5}$ However, this distinction cannot be transposed to languages where Man was not the default word for human being, for example, German (Menschenrecht/e), the Scandinavian languages (menneskerettigheder) and Finnish (ihmisoikeus/ihmisoikeudet), where the distinction between singular and plural rights and the equivocation of 'rights' (Rechte, oikeudet) and 'justice' (Recht/Gerechtigkeit, oikeus/oikeudenmukaisuus) was more pertinent.

Erkki Vala is the main protagonist of this study, but he was far from alone. When a Finnish League for Human Rights (Ihmisoikeuksien Liitto) was founded in November 1935, Vala was among its founding members. The Finnish League for Human Rights maintained few international contacts and

\footnotetext{
${ }^{1}$ Cf. Stefan-Ludwig Hoffmann, 'Genealogies of Human Rights' in Stefan-Ludwig Hoffmann (ed), Human Rights in the Twentieth Century (Cambridge University Press 2010) 1-26. For 'the human rights expansion', see Miia Halme, Human Rights in Action (Helsinki University Printing House 2008) 7-8.

${ }^{2}$ Hoffmann (n 1) 1-2.

${ }^{3}$ Samuel Moyn, The Last Utopia. Human Rights in History (Belknap Press of Harvard University Press 2010$) 12$.

${ }^{4}$ Lorrin Thomas, 'When We Talk About Human Rights' (2015) 6(2) Humanity: An International Journal of Human Rights, Humanitarianism, and Development 349-350.

${ }^{5}$ Moyn (n 3) 25.
} 
it is not mentioned at all in the recent overview Human Rights Leagues in Europe (1898-2016). ${ }^{6}$ Yet its impact on the public debate as well as the secret police indirectly led to the downfall of the longestlasting Finnish government until 1987 and the foundation of the first 'red earth' government in Finland. ${ }^{7}$ It attempted to widen the scope of the rights discourse in Finland to include even noncitizens and marginalized groups such as political prisoners or those affected by eugenic policies, but it was treated as a potential front for Communist infiltration by the authorities. This article analyses the process that led these advocates of 'human rights' to the idea that rights could be evoked against the abuses of state power.

The chair of the League was Väinö Lassila (1896-1939), professor of anatomy at the University of Helsinki. Lassila was a 'reformed' eugenicist, who devoted his public activism to the rights of the congenitally ill and other groups targeted by discriminatory policies such as compulsory sterilization. ${ }^{8}$ The League's interwar activities were discontinued upon his death in April 1939. ${ }^{9}$ This article will focus on Vala's and Lassila's connections and the activities of both the Tulenkantajat journal and the League for Human Rights from the days of their founding until their closure in 1939, based on their publications, personal archives, and the archives of the Central Detective Police, later State Police (1919-1938: Etsivä Keskuspoliisi, a.k.a EK; 1938-1948: Valtiollinen Poliisi a.k.a. Valpo), the secret police of Finland.

A concept evolves and is checked and curtailed by its contradictory use by proponents and opponents. Applying the idea of a 'concept of movement' by Reinhart Koselleck, it can be shown that 'human rights' became a rallying cry for political change toward the 1930 s. ${ }^{10}$ The 'small lacuna' that my article intends to fill in the Finnish case concerns how and why activists [...] articulated their concerns via a range of terms that included 'civil liberties', 'rights of man', and 'human rights' during that

\footnotetext{
${ }^{6}$ Wolfgang Schmale and Christopher Treiblmayr (eds.), Human Rights Leagues in Europe (1898-2016) (Franz Steiner Verlag 2017).

7 A 'red earth' government denotes a coalition of socialist and agrarian interests, in this case including the social liberal wing of the National Progressive Party and the Swedish People's Party. Juhani Paasivirta, Finland and Europe: The Early years of Independence, 1917-1939 (Suomen Historiallinen Seura 1988) 437.

${ }^{8}$ Mikko Niemi, 'Kallojen keskeltä rauhaan ja valoon' in Ilkka Taipale (ed), Mikko Niemi: Sivistynyt lääkäri. Kirjoituksia. (Kustannus Oy Kunnia 2004) 126-127, 131-133; Ainur Elmgren, 'The Nazi's Cloven Hoof: Finnish critiques of legal sterilization', in Johannes Kananen, Sophy Bergenheim and Merle Wessel (eds), Conceptualizing Public Health Historical and Contemporary Struggles over Key Concepts (Routledge 2018) 46.

${ }^{9}$ Niemi (n 8) 136.

${ }^{10}$ Reinhart Koselleck, Vergangene Zukunft - Zur Semantik geschichtlicher Zeiten (Suhrkamp 1989) 339-341.
} 
early period". ${ }^{11}$ Historical contextualization of the concept challenges the apolitical perception of human rights today. ${ }^{12}$

\section{Brief Historical Background to the National Political Context of Early Independent Finland from the February Manifesto 1899 to the Constitution of 1919}

Previously an integral part of the Kingdom of Sweden, Finland became an autonomous Grand Duchy ruled by the Russian Emperor as Grand Duke in 1809. Finland kept its own constitution, government and economy, and developed a national culture in two languages, Swedish being the sole language of administration until the rise of Finnish linguistic nationalism in the mid-century. The struggle between the two languages was mainly a concern for the upper middle classes. Although the budding labour movement in the late $19^{\text {th }}$ century favoured Finnish as the language of the majority, it recognized the existence and needs of Swedish-speaking workers and peasants. In the late $19^{\text {th }}$ century, rising nationalism in Russia inspired policies from the Emperors Alexander III and Nicholas II that endangered the autonomy of Finland. These policies of 'Russification' briefly united the different political and linguistic groups in Finland. Throughout the 1900s and the 1910s, the struggle to protect the Finnish constitution and the struggle for a democratic reform of the four-estate Diet ${ }^{13}$, both united and split the political landscape. ${ }^{14}$

This paradox can be explained with a closer look on how the concept of human rights was used during this period. In a situation where the rights of the state itself are endangered by outside forces, human rights may be invoked rhetorically as the foundation for state rights and civil rights. It was not mere semantic 'slippage' when the French League for the Rights and Liberties of Man supported the Finnish independence struggle before $1917 .{ }^{15}$ Despite what has been described as an apparent

\footnotetext{
11 Thomas (n 4) 340-341.

12 Halme (n 1) 69; Päivi Leino-Sandberg, Particularity as Universality - The Politics of Human Rights in the European Union (Publications of the Erik Castrén Institute of International Law and Human Rights 2005) 44.

13 The four-estate Diet of Finland, consisting of elected representatives of the clergy, the bourgeoisie and the peasants, dated from the time of Swedish rule. Because of limitations on franchise, it has been estimated that the estate diet represented "perhaps a little over 30 per cent" of the population. Juhani Paasivirta, Finland and Europe: The Period of Autonomy and the International Crises, 1808-1914 (University of Minnesota Press 1981) 132.

${ }^{14}$ My summary relies heavily on the following English-language articles: Antti Kujala, 'Finland in 1905: The Political and Social History of the Revolution' in Anthony J. Heywood and Jonathan D. Smele (eds), The Russian Revolution of 1905: Centenary Perspectives (Routledge 2013) 79-93; Pertti Haapala, 'The Expected and Non-Expected Roots of Chaos: Preconditions' in Tuomas Tepora and Aapo Roselius (eds), The Finnish Civil War 1918: History, Memory, Legacy (Brill 2014) 21-50.

${ }^{15}$ For the presumption of 'slippage', see Thomas (n 4) 343.
} 
'vanishing' of 'the rights of man' from European politics in the long nineteenth century, or its replacement by 'civil liberties' from international law and state constitutions, ${ }^{16}$ the concept did not disappear from public discourse, but captured the imaginations of popular movements, including the socialist labour movement. Gregory Claeys notes that "socialists have often supported what look like rights claims where such rights have not been frequently recognised by their liberal counterparts". ${ }^{17}$ Numerous songs and poems of the Finnish labour movement testify to the struggle for human rights in the singular or plural. ${ }^{18}$ The clear majority of the Finnish labour movement supported the national constitution - and civil rights - together with the Finnish bourgeoisie against Russian imperialism. ${ }^{19}$

Although the majority of the protests were peaceful, political violence did take place. The Russian Governor-General, the Emperor's representative in the Grand Duchy, was assassinated in 1904. However, it was the Empire's defeat in the Russo-Japanese war in 1905 and the ensuing general strikes across the Empire, including Finland, which briefly enabled reforms to take place. ${ }^{20}$

The election reform of 1906 introduced universal suffrage equal political rights to all Finnish citizens of age, regardless of gender. However, several criteria limited a citizen's right to vote and right to be elected, affecting up to 15 per cent of the population. ${ }^{21}$ The right to vote and stand for election was not applicable to citizens in military service, to those receiving poor relief, to loss of civil rights (e.g. in the case of the crimes against the state), to those under private or public guardianship, vagrants, unregistered, or electoral frauds. ${ }^{22}$ Finnish legal experts argued that the individual did not exercise their political rights for their own personal benefit, but for the general good. The prerequisite for the use of political rights was the individual's moral, free, self-aware and personal activity on behalf of

\footnotetext{
${ }^{16}$ Hoffmann (n 1) 6-7.

${ }^{17}$ Gregory Claeys, 'Socialism and the language of rights: the origins and implications of economic rights' in Pamela Slotte and Miia Halme-Tuomisaari (eds), Revisiting the Origins of Human Rights (Cambridge University Press 2015) 213.

18 'Internationale', Kommunistinen kalenteri 1921 (V.K.P.:n Suomalaisten Järjestöjen Keskus-Toimisto 1920) 29; Emil Lindahl, 'Oi, kuulkaa köyhälistönaiset...' (1921) 3-4 Työläisnainen 3; Niku Nousio, 'Nyt aika on' (1922) 14 Nykyaika 12; V. Salmi, 'Nouskaa orjat' (1922) 18 Nykyaika 13; 'Puutyöläisten marssi' (1927) 9 Puutyöläinen 139; 'Sisko' (pseudonym), 'Tie Vapauteen' (1928) 5 Tie Vapauteen p. 27; 'Toivo Pirstale' (pseudonym), 'Nousi raittiuden eestä taisto' (1929) 3 Taisteluun 2.

${ }^{19}$ Hannu Soikkanen, 'Sosialidemokraattisen työväenliikkeen itsenäisyyspoliittinen linja' in Juha Hannikainen et al. (eds), Väki voimakas 4 - Suomi 1917-1918 (Työväen historian ja perinteen tutkimuksen seura 1990) 79-94; Jussi Kurunmäki, '"Nordic Democracy" in 1935' in Jussi Kurunmäki and Johan Strang (eds), Rhetorics of Nordic Democracy (Finnish Literature Society 2011) 50-51.

${ }^{20}$ For the events of 1905, see Kujala (n 14); Haapala (n 14) 31.

21 Juhani Mylly, Edustuksellisen kansanvallan läpimurto (Edita 2006) 150, 305-306.

${ }^{22}$ Minna Harjula, 'Köyhä, kelvoton, kansalainen? Köyhäinapu yleisen äänioikeuden esteenä Suomessa' (2010) 18(1) Janus 4.
} 
the state, that is, for a higher goal than personal benefit. Nature herself had put limitations on these abilities. $^{23}$

This restrictive view on political rights must be seen in the political context of the 1906 reforms. Finland was propelled from an ancient system of Four Estates to a single-chambered parliament and votes for men and women. ${ }^{24}$ The first parliamentary elections of 1907 revealed that an absolute majority of the voters supported the Social Democratic Party, hitherto an underestimated force in the eyes of the 'old' parties representing the bourgeoisie: the conservative Old Finns, the radical Young Finns, and the liberal Swedish Party. ${ }^{25}$ Another new party, the Agrarian Union, aspired to represent the peasants, uniting Christian conservatism with demands for relatively egalitarian social policies. This revelation was a shock to many educators and intellectuals. Both the Social Democratic Party and the Agrarian Union were condemned as merely representing class interests, while the smaller bourgeois parties claimed to represent the whole nation (or linguistic group). The susceptible voters, conservatives and liberals argued, had to be educated so that they would not fall into the trap of agitators. Already before the 1906 reforms, the emerging political conflicts frightened conservatives to protest the methods of mass politics: "You declare equality / and formulate human rights, / but you demand power for the rabble / and agitate for riots." 26

These prophecies of doom came true when political hate speech escalated on every side in the public discourse during the revolutionary year $1917 .{ }^{27}$ Finland had remained relatively side-lined during the First World War and was exempt from the draft. However, the presence of Russian military and fortification works against a threat of German invasion contributed to a growing local unease with the wartime conditions, including rationing. Many young men travelled clandestinely to Germany to receive military training. After the February Revolution in 1917, the Provisional Government reinstated Finnish privileges but retained the right to disband parliament. ${ }^{28}$ Social Democrats lost their parliamentary majority in the summer, which led to widespread discontent and resentment among their supporters. ${ }^{29}$ Late 1917 was rocked by strikes and food riots, while Russian sailors and

\footnotetext{
23 Rafael Erich, 'Yleisen äänioikeuden “rajoituksista”' (1908) 3(6) Lakimies 111; Harjula (n 22 ) 3.

${ }^{24}$ Haapala (n 14) 21-50.

${ }^{25}$ Haapala (n 14) 27, 32.

${ }^{26}$ Valter Juva, 'Tersites' (1904) 3 Liitto 150.

${ }^{27}$ Haapala (n 14) 32. For examples of the escalation of public discourse in 1917, see Ainur Elmgren, '"The Jesuits of our time": The Jesuit Stereotype and the Year 1917 in Finland' (2018) 5(1) Journal of Jesuit Studies 9.

${ }^{28}$ Pertti Haapala and Marko Tikka, 'Civil War in Finland in 1918' in Robert Gerwarth and John Horne (eds), War in Peace: Paramilitary Violence in Europe after the Great War (Oxford University Press 2013) 78.

${ }^{29}$ Pauli Kettunen, Poliittinen liike ja sosiaalinen kollektiivisuus: Tutkimus sosialidemokratiasta ja ammattiyhdistysliikkeestä Suomessa 1918-1930 (Suomen Historiallinen Seura 1986) 87.
} 
soldiers attacked their own officers. ${ }^{30}$ Competing forces of order were established by the labour unions as well as representatives of the bourgeoisie. ${ }^{31}$ After the October Revolution, negotiations with the Bolsheviks for independence began. The parliament of Finland adopted a Declaration of Independence 6 December 1917.

However, the complicated political power struggle between the Finnish parties did not lead to a peaceful independence process after this date. The opposing sides organized their forces and armed themselves with the equipment of the Russian military still stationed in the country. The right-led government nominated the bourgeois 'White' guards only as its troops in early January 1918. A fullscale civil war broke out toward the end of the month as the Social Democratic Party leaders bowed to the pressure of the labour guards and declared a takeover in Helsinki. The bourgeois government fled to the north, where it organized resistance. Propaganda on both sides emphasized the antagonists' reliance on external support: The Whites received trained military volunteers from Sweden and the support of the German Baltic Sea Division, while the Reds requested materials from Soviet Russia. Because of the peace negotiations with Germany, Soviet support was short-lived. The civil war was over by May 1918, and tens of thousands of Reds either escaped abroad or were interned in prison camps under miserable conditions over the summer. ${ }^{32}$

As Finland was still formally a constitutional monarchy, the rump parliament - lacking a third of its members, the Social Democrats - elected a German king. The defeat of Germany in November 1918 put an end to the monarchist interlude, and after the election of 1919, republicans (including reformist Social Democrats) regained a majority in parliament and adopted a republican constitution. ${ }^{33}$

The Republic of Finland was a compromise between the victors of in the civil war of 1918, whose lowest common denominator was the struggle against a Socialist revolution. It was the unexpectedly ripened fruit of a legalistic struggle for independence, the defence of the Finnish constitution against Imperial autocracy. These struggles for maintaining the state's rights, as well as increasing the citizen's rights, were conceptually interconnected. State rights and civil rights were 'human rights'. The legalist tradition in Finland was an heir to the eighteenth-century revolutionaries who could not imagine civil and human rights outside of the nation-state. ${ }^{34}$ The struggle around the concept of

\footnotetext{
${ }^{30}$ Haapala and Tikka (n 28) 78.

${ }^{31}$ Tuija Hietaniemi, Lain vartiossa. Poliisi Suomen politiikassa 1917-1948 (Suomen Historiallinen Seura 1992) 38-39, 47-49.

32 This paragraph is a summary of Haapala and Tikka (n 28) 76-80.

${ }^{33}$ Raija-Leena Loisa, 'Monarchism, Republic and Parliamentary Government: Finland after the Civil War' in Kari Palonen et al. (eds), The Politics of Dissensus: Parliament in Debate (Cantabria University Press 2014) 149-170.

${ }^{34}$ Hoffmann (n 1) 2.
} 
human rights in the following decades would pinpoint the difficulty in challenging this view, even to protect the human individual's rights against the state. The fear of the revolutionary masses made many bourgeois conservatives and liberals emphasize the protection of the state at the expense of the individual, after 1905 as well as $1918 .^{35}$

\section{Civil Rights and Human Rights as Contested Synonyms in early $20^{\text {th }}$ Century Finland}

Erkki Vala has been described as one of the few "free intellectuals" in interwar Finland, who claimed the role of an intellectuel engagé speaking truth to power. ${ }^{36}$ Despite this emphasis on freedom, Vala's agency was limited by the political culture in Finland. Therefore, it is necessary to include an overview of the historical preconditions of Vala's activities in the interwar era, and the liberal, conservative and socialist uses of the concept of 'human rights' that he inherited.

Not every use of 'human rights' made it a positive 'concept of movement'. According to Gregory Claeys, "socialism played some role in the 'decline and hibernation' of natural rights-based discourses $[. .$.$] from the mid-nineteenth to the mid-twentieth centuries", if only by its scare factor. { }^{37}$ Instead of claiming the concept, as the European 'conservative human rights movement' ${ }^{38}$ after the Second World War, some Finnish conservatives in the 1920s even argued that national independence had made the concept of human rights obsolete. The rhetoric of the Social Democratic Party, which was focused on the rights of the political prisoners since the civil war, was held to be a significant threat against national unity. For many victorious 'Whites', it made little sense to distinguish between those Social Democrats that had resisted the revolt and the unrepentant Moscow exiles that split from the party in the autumn of 1918 to form a Finnish Communist Party (later renamed Communist Party of Finland) that joined the Third International. This Communist party was immediately prohibited in Finland, but it carried on an underground existence until 1944. Its activities were consequently of considerable interest to the secret state police of Finland, the Central Detective Police, founded in

\footnotetext{
${ }^{35}$ Kukku Melkas and Olli Löytty, 'Jalon sivistyneistön kuriton kansa' in Pertti Haapala et al. (eds), Kansa kaikkivaltias: Suurlakko Suomessa 1905 (Teos 2008) 237.

${ }^{36}$ Erkki Sevänen, 'Ensimmäisen tasavallan poliittinen tilanne ja kirjallisen älymystön toimintastrategiat' in Pertti Karkama and Hanne Koivisto (eds), Älymystön jäljillä - kirjoituksia suomalaistesta sivistyneistöstä ja älymystöstä (Suomalaisen Kirjallisuuden Seura 1997) 51-52.

${ }^{37}$ Claeys (n 17) 232; Jeremy Waldron, 'The Decline of Natural Right' in Allen W. Wood and Songsuk Susan Hahn (eds), The Cambridge History of Nineteenth Century Philosophy (Cambridge University Press 2012) 649.

${ }^{38}$ Marco Duranti, The Conservative Human Rights Revolution, European Identity, Transnational Policis, and the Origins of the European Convention (Oxford University Press 2017).
} 
1919, and every debate on civil and human rights in the country was in one way or another influenced by its real or perceived attempts at gaining an ideological foothold among the population. ${ }^{39}$

In the years directly after the Civil War of 1918, the Social Democratic press, recovering from initial crackdowns, used the terms 'human rights' (ihmisoikeudet) along with 'civil rights' (valtiolliset oikeudet, lit. 'state rights') in a call to protect the rights of prisoners of war and political prisoners. Familiar claims were grounded in revolutionary discourse and described as human rights - although there was no Universal Declaration to link these claims to. ${ }^{40}$ The Constitution of 1919 , which remained in force until 2000, expressly guaranteed only the right to work and the right to education. ${ }^{41}$

Political prisoners who had received sentences for sedition in 1918 lost their right to vote and stand in elections for several years. The loss of political rights also meant a social stigma. Possibly because of such wider repercussions, the Social Democratic press applied the label 'human rights' to these political rights. ${ }^{42}$ The Social Democratic Party in Finland, like its sister parties in the interwar era, drew upon the language of national resistance and independence struggle and connected human rights to popular sovereignty. ${ }^{43}$ In its election manifesto of 1919, the party listed among its demands "full and equal human and civil rights to all citizens". ${ }^{44}$ Party chair Väinö Tanner defended the election manifesto in court, admitting that it meant the most severe condemnation of the "oppressors [of the people] who had trampled human and civil rights under their feet" ${ }^{45}$

Arguably, the Social Democratic demands were not asking for 'human rights' in the modern sense, but the restoration of civil rights; "freedom in and through the state", not "freedom from the state" ${ }^{46}$ However, because of its use in appeals on behalf of political prisoners, 'human rights' became a politically tainted phrase in 1919. The bourgeois press associated calls for 'human rights' with blood-

\footnotetext{
${ }^{39}$ For the history of the Communist Party of Finland and its activities in English, see Tauno Saarela, Finnish Communism Visited (The Finnish Society for Labour History 2015); Kimmo Rentola and Tauno Saarela, Communism: National and International (Finnish Historical Society 1998).

40 Thomas (n 4) 350.

${ }^{41}$ Heikki Karapuu and Allan Rosas, 'The Juridical Force of Economic, Social and Cultural Rights - Some Finnish Examples' (1988) 6 Mennesker og rettigheter - Nordic Journal on Human Rights 37.

42 'Camorran tuomitsema' Hämeen Kansa (Hämeenlinna 19 November 1919) 1; 'Humppilan työläiset kunnalliswaaleihin' Hämeen Kansa (Hämeenlinna 27 November 27) 4; E[vert] Huttunen, 'Sos.-dem. edustajain lausuntoja wiime keskiwiikkoisessa eduskunnan istunnossa tapahtuneesta rauhan keskustelusta' Kansan Voima (Joensuu 7 December 1920) 1; 'Työkansan mielipide", Savon Kansa (22 December 1920); 'Kirje Topenolta' Hämeen Kansa (Kuopio 28 December 1920) 4; 'Uudenvuoden kynnyksellä' Kansan Voima (Joensuu 30 December 1920$) 1$.

${ }^{43}$ For the German and the French parties, see Hoffmann (n 1) 9-10.

44 'Mitä sosialidemokratia vaatii?' Suomen Sosialidemokraatti (Helsinki 20 February 1919) 5.

${ }^{45}$ Väinö Tanner, Det vita väldet i Finland - Försvarstal hållet inför rådstuvurätten i Helsingfors den 17 mars 1919 med anledning av åtal, väckt mot Socialdemokratiska Partistyrelsen för partiets valmanifest (Styrelsen för Finlands Socialdemokratiska Parti 1919) 67.

${ }^{46}$ Hoffmann (n 1) 9-10.
} 
curdling phrases as typical 'vengeful' propaganda of the left. ${ }^{47}$ Due to the observed connection between rights discourse and the revolutionary labour movement, many on the opposing side were reluctant to use the concept at all. Internationalist appeals were especially viewed with suspicion. ${ }^{48}$

\section{Liberal Individualism and Human Rights}

According to Samuel Moyn, national rights struggles before the Second World War were more likely to involve invocations of individual rights, and took for granted an existing space of inclusive citizenship in which said claims could be given meaning. ${ }^{49}$ However, those who spoke literally about 'human rights' in Finland in the 1930s did so to defend individuals as much as marginalized groups that were excluded from those groups that had rights, e.g. citizens of a state. Individual rights could be considered morally dubious in a culture emphasizing self-sacrifice, as demands for rights were often negatively interpreted as selfish demands for individual gain. ${ }^{50}$ While scholars like Marco Duranti have shown how conservatives during the interwar economic crisis utilized rights rhetoric against state intrusion and control, the case of Finland in 1917-1939 reveals some national particularities. Human or civil rights were a rhetorical tool that could easily be turned against liberalism, too. ${ }^{51}$ Limitations of rights were rationalized as 'healthy demands of democracy', especially after $1918 .^{52}$

New and experimental ideas about liberties and rights still found their way to a circle of young writers and poets, known as Nuoren Voiman Liitto (NVL, Union of Young Effort). NVL was a cultural organization modelled on the popular scouting movement, awarding medals for achievements and led by former Boy and Girl Scouts, including Erkki Vala and Ensio Hiitonen. ${ }^{53}$ It strove to inspire a post-Civil War generation of young Finns who would unite their efforts in the fields of culture and

\footnotetext{
47 'Sosialistien vaalijulistus' Etelä-Savo (Lappeenranta 15 February 1919) 2; Sulo Heiniö, 'Suojeluskuntaliikkeestä' Helsingin Sanomat, (Helsinki 14 November 1919) 8.

48 'Dollarin oikeus ja ihmisyyden oikeus' (1927) 9 Suomen Ammattijärjestö 173-175; 'Topi' (pseudonym),

'Tyytymättömyyttä oleviin oloihin' Keski-Uusimaa (Hyrylä 24 August 1929) 3.

${ }^{49}$ Moyn (n 3) 33.

50 'Piirteitä Fr. V. Foersterin kasvatusopista' (1918) 18-24 Kansakoulun lehti 233.

51 Moyn (n 3) 35-36; Duranti (n 38).

${ }^{52}$ M. A., 'Kansanvallan puolesta' Maaseutu (Hamina 2 August 1919) 2.

53 Kai Häggman, Piispankadulta Bulevardille. Werner Söderström osakeyhtiö 1878-1939 (WSOY 2001) 307; Juho Karjalainen, Tieteen popularisointi vuosina 1925 - 1928 julkaistussa lehdessä Valo: Tiedettä kaikille (University of Oulu 2014) 105-106.
} 
science. ${ }^{54}$ Much like the scouting movement in Finland, its outspoken goal after 1918 was to reunite a nation split by social and ideological differences. ${ }^{55}$ Ideas that were labelled "utopian" attracted this post-war generation - Pan-Europeanism, the Esperanto movement, and others. ${ }^{56}$ These ideas could increase the attraction of the underestimated "utopian dimension of universal human rights theories". ${ }^{57}$ The NVL journal glimpsed such an interwar utopia via a photo of a peaceful celebration between German and French students organized by the German League for Human Rights. ${ }^{58}$ Here, Ensio Hiitonen began to connect the struggle for rights with the appreciation of individuality - the former becoming the precondition for the latter. ${ }^{59}$ With an article about the political economist Henry George, Hiitonen connected the struggle for human rights with the struggle against economic inequality. ${ }^{60}$

Because the neo-Hegelian idealism of Finnish nationalism claimed that the development of a personality could only be fulfilled within the national state project ${ }^{61}$, Hiitonen argued that fulfilment of individuality was not possible without organizing society to the benefit of all its members, taking into account the material conditions enabling a free discovery and development of talent. ${ }^{62}$ The underlying premise was that the individual, regardless of background, had certain 'rights', and it would be to the benefit of society and the state to protect these rights. However, the influential nationalist student movement was hostile to political views that did not agree with their programme. Because of his individualist views, Hiitonen was ridiculed as an 'old fogey' in the main student paper Ylioppilaslehti in the mid-1920s. ${ }^{63}$

\footnotetext{
${ }^{54}$ Matti Virtanen, Fennomanian perilliset - Poliittiset traditiot ja sukupolvien dynamiikka (Suomalaisen Kirjallisuuden Seura 2002) 143-146.

55 Mervi Kaarninen, Nuoren tasavallan nuorison ongelmat - Nuoruuden vuosisata. Suomalaisen nuorison historia (Suomalaisen Kirjallisuuden Seura 2003) 82-83, 94.

${ }^{56}$ Although Coudenhove-Kalergi's Paneuropa project was a conservative effort, in Finland it mainly attracted leftliberals with its transnational utopian objectives. For Coudenhove-Kalergi, see Duranti ( $\mathrm{n} 38$ ) 73. On the reception in Finland, see Heikki Isotalo, 'Hitaasti kiiruhtaen kohti Paneurooppaa - Euroopan yhdentymisen aate Suomessa 19181939' (MA thesis, University of Helsinki 2016).

${ }^{57}$ Claeys (n 17) 233.

58 no title (1929) 17-18 Nuori Voima 16.

${ }^{59}$ K. E. P. H. (Kaarlo Ensio Paulus Hiitonen, 'Ajatuksenvapauden marttyyri ja hänen aatteensa' (1923) 1 Nuori Voima 17.

${ }^{60}$ K. E. P. H. (Kaarlo Ensio Paulus Hiitonen, 'Yhteiskunnallisten ongelmain suuri ratkaisija - Henry George, ihmisoikeuksien puoltaja' (1923) 13-14 Nuori Voima 391.

61 "Right, for Hegel, was not a matter of nature, but of culture and, as such, it was historical, changeable and developing." Jari Pirjola, 'Culture, Western Origin and the Universality of Human Rights' (2005) 1 Nordisk Tidsskrift for Menneskerettigheter 12; see also Duranti (n 38) 69.

${ }^{62}$ Ensio Hiitonen, 'Huonon osajaon pilaama näytelmä' in Uuno Kailas et al. (eds.), Tulenkantajat. Nuoren Voiman Liiton kirjallisen piirin albumi (WSOY 1924) 169.

${ }^{63}$ Anonymous, 'K. E. P. H:n "sodanjulistus"' (1923) 18 Ylioppilaslehti 315; 'Pekka ja livana' (pseudonym), 'Kirje K. E. P. H:Ile' (1926) 3 Ylioppilaslehti 6.
} 
The National Progressive Party, the liberal party that Erkki Vala supported until the early 1930s, carried on the legacy of the civil rights activists of the independence struggle. Its politicians, like Einar Böök, who wrote a genealogy of "The Rights of Man and Citizen" in 1910, went on to work on behalf of practical reforms in social and public health legislation. ${ }^{64}$ The spirit of reform enlivened the efforts of many young Finns who believed in the nation as a meritocracy, but also felt the appeal of radically egalitarian voices. During the 1920's, young Erkki Vala had been considerably influenced by his friendship with the author Arvid Järnefelt. Born in 1861, Järnefelt belonged to the older generation of Finnish independence activists, inspired by the Christian anarchism of Leo Tolstoy. ${ }^{65}$ Together with his wife Emilia, Arvid Järnefelt founded a school for workers' children and supported the local labour movement. Many members of the Nuoren Voiman Liitto and the early Tulenkantajat journal (1928-1930) visited the Järnefelts to volunteer on their farm. Järnefelt was a successful novelist, but he also translated works by thinkers close to his ideals, such as Henry George, whom Ensio Hiitonen described as "defender of human rights" in $1923 .{ }^{66}$ George had advocated land reform and Järnefelt wrote his own take on the topic, "The Land Belongs to All”, after some brutally suppressed crofter strikes in $1907 .^{67}$

Although the Agrarian Union pushed through land reforms after 1918 with the goal of appeasing the landless, there was little room for progressive debate on the conditions of industrial workers, the driving force behind the attempted revolution. Reconciliatory measures towards the losing side in the Civil War could be met with violent reactions. Vala later recalled the shock of the assassinations of liberal Minister of the Interior Heikki Ritavuori in 1922 and socialist municipal politician Onni Happonen in $1930 .^{68}$

If the radicalism of the Social Democratic Party in 1917-1918 had driven the petty bourgeoisie and the farmers into the arms of the conservatives, ${ }^{69}$ it was the complaisance of bourgeois Finland toward the anti-parliamentary, violently anti-socialist Lapua movement in 1929-1932 that drove progressives

\footnotetext{
${ }^{64}$ Einar Böök, Edistyksen uralta (Edistysseurojen Kustannus-Osakeyhtiö 1919) 11-26. Böök's genealogy, composed in 1900, adhered closely to the 'Germanic' tradition proposed by his contemporary, Georg Jellinek. Jellinek's interpretation remained among the most well-known in Finland, cf. K. R. Brotherus, 'Muutamia piirteitä n.s. vapausaatteiden historiasta' (1929) 4 Historiallinen Aikakauskirja 257. For Jellinek, see Duncan Kelly, 'Revisiting the Rights of Man. Georg Jellinek on Rights and the State' (2004) 22(3) Law and History Review 493.

${ }^{65}$ Archive of the Finnish Literature Society, Vala, Erkki, SKS 25318, file 3, interview 5.11.1973, tape 1, track a; interview 10.12.1973, tape 3, track b; Erkki Vala, 'Romantik och realism kring Tulenkantajat' Hufvudstadsbladet (Helsinki 6 July 1969) 7.

${ }^{66}$ K. E. P. H. (n 60) 391.

${ }^{67}$ Arvid Järnefelt, Maa kuuluu kaikille! Matkoiltani Laukon lakkomailta (Vihtori Kosonen 1907).

${ }^{68}$ Archive of the Finnish Literature Society, Vala, Erkki, SKS 25318, file 3, interview 10.12.1973, tape 3, track b.

${ }^{69}$ Yrjö Kivimies, Pidot Tornissa (Gummerus 1937) 318-319.
} 
into the arms of the left. In 1930, new legal restrictions to civil rights were introduced, namely to the freedoms of speech and association ("law on the protection of the republic"), to appease the Lapua leaders. In 1932, the Lapua movement's most militant wing attempted a coup. While its leaders were sentenced to relatively mild prison sentences, the movement reorganized as a Fascist-inspired party, the Patriotic People's Movement, which demanded the prohibition of the Social Democratic Party. Erkki Vala joined the Social Democratic Party in solidarity. The attempted coup inspired him to start publication of Tulenkantajat after a three-year hiatus, concluding that 'cultural workers' must unite their forces with the working class to be able to define the national interest on their own terms. ${ }^{70}$

Limitation of civil rights continued during the decade. In 1934, a "law to prevent agitation harmful to society and legal order" (popularly known as kiihotuslaki, 'agitation law') was passed. Tulenkantajat opposed it openly. The "law on the protection of the republic" was abolished in 1935, but the 1934 'agitation law' continued to be enforced, sometimes arbitrarily. Vala was fined in 1935 and briefly imprisoned in 1936 for crimes against this 'agitation law'. ${ }^{71}$ He perceived, not entirely unjustly, ${ }^{72}$ that he was a target of the authorities, commenting sarcastically:

... [The] only way to avoid press trials in our clerical state is to begin a campaign for general dismemberment of human beings through capital punishment, castration and caning. This is not [seen as] agitation, but true patriotism. ${ }^{73}$

Civil rights and liberties were attacked, not only by the extreme right, but also - and perhaps more importantly - by centrist and even liberal politicians and officials that wanted to protect the state from its enemies by any means necessary. Jurist and budding Agrarian politician Urho Kekkonen published the pamphlet Demokratian itsepuolustus ('The Self-Defence of Democracy') in 1934, after witnessing the rise of Hitler in Germany. However, the pamphlet was as much an attack against liberalism as against anti-democratic ideologies. Instead of a contract between citizen and state, Kekkonen's 'democracy' was the nation-state as a body politic. According to Kekkonen, liberals

\footnotetext{
70 Erkki Vala, 'Kansallinen ja epäkansallinen' (1933) 5 Tulenkantajat 1.

${ }^{71}$ Erkki Sevänen, Vapauden rajat: kirjallisuuden tuotannon ja välityksen yhteiskunnallinen sääntely Suomessa vuosina 1918-1939 (Suomalaisek Kirjallisuuden Seura 1994) 134.

72 Lars Björne, "...syihin ja lakiin eikä mielivaltaan..." Tutkimus Turun hovioikeuden poliittisista oikeudenkäynneistä vuosina 1918-1939 (Suomalainen Lakimiesyhdistys 1977) 248-249; Kari Sallamaa, Kansanrintaman valo Kirjailijaryhmä Kiilan maailmankatsomus ja esteettinen ohjelma vuosina 1933-1943 (Suomalaisen Kirjallisuuden Seura 1994) 69-70.

73 'Merkillepantavia asioita’ (1935) 7 Tulenkantajat 2.
} 
defined civil rights too generously and paved the way to 'foreign theories of dictatorship', such as Fascism and Communism. ${ }^{74}$ In his view, the Finnish people had volunteered to limit its own rights to stop Communism. ${ }^{75}$ Alluding to this pamphlet, Erkki Vala wrote in 1935: "Even the defenders of democracy had too often forgotten that democracy was founded on the principles of human rights" ${ }^{76}$

Kekkonen, who had worked for the Central Detective Police in the 1920s, had certainly reason to believe that the underground Communist Party was attempting to infiltrate Finland. In November 1934, a widely publicized trial began against a captured Communist agent. The trial would galvanize pacifists, liberals and civil rights activists in an anti-capital punishment campaign and lead to the founding of a League for Human Rights in Finland. Toivo Antikainen, the accused, was a former Red Guard who had escaped to Soviet Russia after the Civil War and participated in the counterattack on Finnish volunteers in the East Karelian anti-Soviet uprising in 1921. Antikainen's actions in this guerrilla war became the topic of public debate upon his capture as a Soviet spy by the Finnish authorities. He was sentenced to life for murder based on claims that his forces had burned a young Finnish volunteer alive. ${ }^{77}$ The right-wing press, dissatisfied with the trial, called for the reintroduction of capital punishment, already included in a law proposal under debate. As Vala, Lassila and other liberals joined the cause against capital punishment, the Central Detective Police surveyed their activities - first petitioning against capital punishment in 1934, then during the Antikainen trial, and culminating with the foundation of the League for Human Rights in December $1935 .^{78}$

\section{The League of Human Rights in Finland}

The Finnish League of Human Rights was founded by liberal intellectuals connected to the National Progress Party, and left-wing Social Democrats. ${ }^{79}$ Despite being modelled on international examples, it appears to have been an independent initiative. Its European sister organizations were falling on

\footnotetext{
74 Urho Kekkonen, Demokratian itsepuolustus (WSOY 1934) 30-31.

${ }^{75}$ Kekkonen (n 74) 36-39.

${ }^{76}$ Archive of the Finnish Literature Society, Erkki Vala, SKS 25318 kansio 8, "Demokratian suurin vaara: Ihmisoikeuksien jatkuva rajoittaminen", speech for Nuortasavaltalaiset (Young Republicans) 25.4.1935, manuscript.

${ }_{77}$ Niemi (n 8) 137.

${ }^{78}$ Hanna-Leena Vuokila, 'Ihmisoikeuksien ja demokratian puolesta! Ihmisoikeuksien liitto 1935-1939 ja 1946-1952' (MA thesis, University of Helsinki 1999) 12-20.

${ }^{79}$ Marja Wahlberg, Syyllisiä kunnes toisin todistetaan - Etsivä keskuspoliisi ja kulttuuriliberaalit 1934-1937

(Suojelupoliisi 2012) 30.
} 
hard times in 1934-35. ${ }^{80}$ In Germany and Poland, the states persecuted the national Leagues. ${ }^{81}$ Leading members of the French League had been tarnished by financial scandals in the early 1930s. ${ }^{82}$ The Central Detective Police could also not produce any specific evidence of foreign connections. ${ }^{83}$ Its agents reported that the founding meeting of the League was attended by approximately two hundred individuals in November 1935. Furthermore, "all the public gatherings of the League [...] have been attended by several known Communists, among them several that have received sentences for sedition". ${ }^{84}$ Although it was difficult to prove how influential the organization was on a greater scale, the authorities decided that the presence of such individuals was a serious matter.

Upon its foundation, the League issued a pamphlet with the following declaration of intent:

Freedom of consciousness, respect for human life, personal inviolability, freedom of speech and association, the equality of citizens before the law [...] equality of women in society, are all recognized as foundational principles of society. These ideas have always been met with great resistance and today they are particularly threatened. [...] The League of Human Rights has been founded to [...] enable citizens to organize actively in favour of these great democratic values and human rights. ${ }^{85}$

Samuel Moyn points out that the Leagues for Human Rights founded during this period "certainly did invoke the liberties of speech, press, and association primarily against the state", but these civil liberties still drew their "ideological authority and cultural premises" from the nation-state. ${ }^{86}$ Pace Moyn, the Finnish League for Human Rights did not claim 'deep national traditions', but rooted its

\footnotetext{
${ }^{80}$ Laurie S. Wiseberg and Harry M. Scoble, 'The International League for Human Rights: the Strategy of a Human Rights NGO' (1977) 7(7) Georgia Journal of International and Comparative Law 292-293.

${ }^{81}$ Emmanuel Naquet, 'The LDH and the Bund Neues Vaterland. The Convergence of Two Human Rights Associations, 1914 to 1939' in Wolfgang Schmale and Christopher Treiblmayr (eds), Human Rights Leagues in Europe (1898-2016) (Franz Steiner Verlag 2017) 89-93; Lora Wildenthal, 'The Reincarnations of the German League for Human Rights in Occupied and West Germany' ibid. 96; Izabela Mrzygłód, 'The League for the Defence of Human and Civil Rights in Interwar Poland (1921-1937)' ibid. 157-172.

82 William D. Irvine, 'War, Peace and Human Rights. The Dilemma of the Ligue des droits de l'homme' in Wolfgang Schmale and Christopher Treiblmayr (eds), Human Rights Leagues in Europe (1898-2016) (Franz Steiner Verlag 2017) 36.

${ }^{83}$ The file is freely accessible at the National Archives of Finland. Valpo I ark. XXV. D2. Amp. 2900, Ihmisoikeuksien Liitto 1. It contains a report from 24 September 1936 stating that the League was founded by the same individuals that took the initiative to the petition against capital punishment, therefore justifying suspicions that the League was a Communist front.

${ }^{84}$ National Archives of Finland. Valpo I ark. XXV. D2. Amp. 2900, Ihmisoikeuksien Liitto 1, note dated 23 April 1936.

85 'Ihmisoikeuksien liitto' (1935) < http://urn.fi/URN:NBN:fi-fd2012-pp00000903 > accessed 26 February 2018

${ }^{86}$ Moyn (n 3) 38.
} 
claims in universal law - at least imagined universality - against national particularism. Moyn is right in noting that "civil libertarians restricted their rhetorical appeals and their activism to the domestic forum", but the League for Human Rights and its individual members did attempt to make international appeals and involve transnational allies in their struggles, albeit on a limited scale.

The League organized lectures and published its own newsletter. Together with Tulenkantajat, it provided a platform for intellectuals promoting the concept of human rights. Väinö Lassila provided the voice of the rational, enlightened scientist, who had actively disengaged from the field of racial anthropology during the 1930s ${ }^{87} \mathrm{He}$ was a particular target for the nationalist right for his political activities and alleged Communist connections. ${ }^{88}$ A far-right newspaper nicknamed him ihmisoikeusLassila ("Human Rights Lassila”). ${ }^{89}$

While Lassila could draw from his experiences in research, Erkki Vala had another personal perspective on the topic of limitations to civil liberties. Numerous individual cases among his collaborators and family members throughout the 1910s until the 1940s, suffering from afflictions such as tuberculosis, mental illness or epilepsy, often exacerbated by poverty, exemplified the potential for arbitrary abuse of laws that limited civil liberties. In 1929, a committee for the preparation of a law on eugenic sterilization stated: "A commonly accepted principle of justice is that the individual's right has to cede, when his and the society's interests are in conflict with each other". ${ }^{90}$ Many sick and disabled people were wholly or partially excluded from the free exercise of civil and individual rights during this time; for example, since 1929, epileptics had to consent to sterilization to be able to marry, and those who were under guardianship had no right to vote. ${ }^{91}$ A few writers had previously voiced concerns for those who had no civil rights according to contemporary law: "for even the mentally ill is a human being, who must be allowed to enjoy his human rights, at least concerning care." 92 Such 'human rights' could simply be taken to mean basic living conditions - not unlike the occasional use of 'human rights' in demands for higher salaries for public servants. ${ }^{93}$ In a

\footnotetext{
${ }^{87}$ Pekka Isaksson, 'Suomalainen rotututkimus ja saamelaiset 1900-luvun alussa' (1997) 2 Historiallinen Aikakauskirja $163,165-167$.

88 'Tapaus Väinö Lassila’ (1939) 3 Ylioppilaslehti 1.

89 'Laukauksia' (1939) 4 Luo lippujen! 91.

90 Markku Mattila, 'Rotuhygienia ja kansalaisuus' in Ilpo Helén and Mikko Jauho (eds), Kansalaisuus ja kansanterveys (Gaudeamus 2003) 122.

${ }^{91}$ Mattila (n 90) 111; Klaus Törnudd, Finland and the International Norms of Human Rights (Martinus Nijhoff Publishers 1986) 189.

92 O. S., 'Piirimielisairaalakysymys' Forssan Lehti (Forssa 14 February 1919) 1; 'Perttulan tylsämielisten kasvatuslaitos' (1922) 4 Suomen Nainen 12.

93 'Kaksimielinen ja kannaton "kanta"' Keskisuomalainen (Jyväskylä 26 May 1929) 1.
} 
novel step, Tulenkantajat connected abuses in the institutionalization of tuberculosis patients and mental patients to the overall questionable state of democracy and civil rights in Finland. ${ }^{94}$

During the passing of the Sterilisation Act in the autumn of 1935, Vala connected it to other attacks against civil rights, such as the simultaneous proposal to widen the scope of capital punishment. He defined the "greatest danger to democracy" as "the continuous limitation of human rights". ${ }^{95}$ Tulenkantajat declared that people in all parties were voicing their disgust towards this law "that deeply offends the individual's rights and the notion of humanity". ${ }^{96}$ Vala could not accept that "another new and terrifying weapon without effective control is put in the hands of the authorities that evidently function in a class society and whose frontline is drawn against the lowest and poorest layers of the people". 97

For Vala, the protection of civil rights came first, even for those who were not fully classified as citizens under contemporary law. It was a precondition for a more egalitarian society. Just as arbitrary abuse of power would target the weakest, including the poorest, in an unequal society, the struggle for civil rights needed to be connected to a critical socioeconomic analysis of society, as Vala argued:

The workers of Finland support Tulenkantajat because the journal fights for the citizens' constitutional rights, including freedom of association, freedom of speech, and the right to read whatever newspapers one wishes, not the ones that their employers impose on them. The workers understand that the standard of living will not be improved upon unless civil rights are guaranteed. ${ }^{98}$

Without spelling it out, Vala agreed with Karl Marx in the notion that rights could never be higher than the economic structure of society and its cultural development conditioned thereby. ${ }^{99}$

\footnotetext{
94 '’'Demokraattinen" Suomi v. 1936' (1936) 42 Tulenkantajat 6; 'Miten huoltolakeja pannaan käytäntöön' (1936) 42 Tulenkantajat 6; 'Meillä sitä ei voi tapahtua' (1936) 48 Tulenkantajat 11; 'Todistuskappaleita "demokraattisesta" Suomesta v. 1937' (1937) 15 Tulenkantajat 7-8.

95 Archive of the Finnish Literature Society, Erkki Vala, file 8, "Demokratian suurin vaara: Ihmisoikeuksien jatkuva rajoittaminen", speech for Nuortasavaltalaiset ('Young Republicans') 25 April 1935, manuscript.

96 'Sterilisoimishumpuuki herättää yleistä vastusta' (1935) 9 Tulenkantajat 3.

97 -a. (pseudonym), 'Liiallista virkavaltaa' (1934) 33 Tulenkantajat 1; 'Yksipuolista asiantuntemusta' (1934) 40 Tulenkantajat 5.

98 'Majava' [Erkki Vala], 'Elintasosta ja kansalaisoikeuksista' (1936) 36 Tulenkantajat 2.

${ }^{99}$ Karl Marx, Capital (International Publishers 1968) 325.
} 
The League of Human Rights in Finland attracted the attention of the Central Detective Police for several reasons. Although it did not attract high numbers, its public activities rallied noteworthy personalities around previously taboo or marginalized issues, such as the political rights of prisoners. ${ }^{100}$ Agents reported on foreign visitors to the League and to Tulenkantajat or visits to the Soviet Embassy. ${ }^{101}$ Another reason was the wide definition of crimes outlined in the 'agitation law' of 1934, which criminalized disturbances of foreign relations, general agitation that could lead to public disturbance, and more insidiously: through 'distortion or insulting words or expressions' to utter or to spread utterances calculated to insult the parliament, the government, public servants, or prevailing state or national order, or 'grossly insult religious or moral principles, or to desecrate national relics'. ${ }^{102}$ Erkki Vala provoked the authorities further by publishing articles from the foreign press that criticized the conduct of the Antikainen trial. ${ }^{103}$

The League was also directly targeted by the Central Detective Police as a cover organization for Communist infiltration according to the decision of the 7th congress of the Comintern in 1935 to support the 'popular fronts' that had been forming in different European countries in response to the rising threat of Nazism and Fascism. ${ }^{104}$ At the request of Prime Minister T. M. Kivimäki in 1935, the Central Detective Police compiled two memoranda listing and analysing clubs and organizations that they considered potential targets for Communist infiltration according to the 'popular front' tactic. ${ }^{105}$

The Central Detective Police collected newspaper clippings expressing criticism of the law itself in its files about Tulenkantajat and the League. ${ }^{106}$ One article by Erkki Vala received the hand-written comment: "No wonder that the popular front needs extensive freedom of speech; and, if prosecuted, [claims] oppression of human rights." 107 The Central Detective Police had thus noted the expansion

\footnotetext{
100 Wahlberg (n 79) 16.

${ }^{101}$ National Archive of Finland, M36 2899 Valtiollisen poliisin I arkisto, Adler, Helmer Karl Aksel hmp 3499, jakso 19, 29. 
of the rights concept from civil rights, which could be taken away for the security of the state, to human rights, which were claimed to be inalienable.

Among its evidence for the 'popular front' tactic of the League, the Central Detective Police collected testimonials by Communists or suspected sympathizers that had participated in its meetings or were being recruited as local representatives. One of the suspects was Betty Peltonen, another former house guest of the Järnefelt family, jailed for her activism in the prohibited Finnish Worker's Party in 1923 and 1925. Peltonen was dismissed from her position as secretary of the League because her membership became a hindrance for the registration of the organization. Väinö Lassila was also suspected of being a Communist mole. The Communist Party had agreed to support Lassila's candidature for the parliamentary elections of 1936 on the list of the liberal National Progressive Party. ${ }^{108}$

Clippings of articles from the right-wing and extreme-right press that accused the League of being a hotbed of Communism were also archived, even though they could hardly have served as hard evidence, such as a claim by the Fascist paper Ajan Suunta about the Polish League of Human Rights: "such organizations, no matter [...] how 'national' their supporters are, always follow the orders of international Jewry". ${ }^{109}$ Conservative papers were usually satisfied with the common-sense answer that human rights were already protected in independent Finland, therefore a League was unnecessary, and suspicions against it were justified. ${ }^{110}$ The main point of contention of the League, the introduction of capital punishment in courts of peace, would actually preserve the most important human right of citizens, meaning their bodily and spiritual integrity. ${ }^{111}$

The popular front memoranda that Prime Minister Kivimäki had requested from the Central Detective Police were revealed to the public after an unlikely chain of events. As the registration of the League of Human Rights was delayed by the Helsinki City Court, the League's members requested to see the court files of their case. Among the files were, by accident, copies of the secret memoranda. ${ }^{112}$ In August 1936, Tulenkantajat and other newspapers published the memoranda. Surviving notes in the

\footnotetext{
108 Wahlberg (n 79) 30-37.

109 National Archive of Finland, M36 2899 Valtiollisen poliisin I arkisto / Asiamapit XXV D2, Ihmisoikeuksien Liitto 1. Ajan Suunta (23 September 1936).

110 National Archive of Finland, M36 2899 Valtiollisen poliisin I arkisto / Asiamapit XXV D2, Ihmisoikeuksien Liitto 1. Uusi Suomi (Helsinki 23 August 1936).

111 National Archive of Finland, M36 2899 Valtiollisen poliisin I arkisto / Asiamapit XXV D2, Ihmisoikeuksien Liitto 1. Karjala (Viipuri 23 August 1936).

112 Wahlberg (n 79) 28. National Archive of Finland, M36 2899 Valtiollisen poliisin I arkisto / Asiamapit XXV D2, Ihmisoikeuksien Liitto 1. Pääministeri Kivimäki 21/9-36.; 21/6-36 Tuomari Tuominen [...]; 21/9-36 Pankko.
} 
Central Detective Police archives reveal that this slip-up caused a shock among the authorities. ${ }^{113}$ Soon, a vote of confidence in Parliament over a law package introduced by the Prime Minister, including the proposed expansion of the law on capital punishment, was decided narrowly to the disadvantage of the government. Two of Kivimäki's liberal party comrades were conspicuously absent. The government fell by one vote - "bitten by my own dogs", the Prime Minister commented. ${ }^{114}$

Even though the fall of the Kivimäki government was celebrated as a victory by Tulenkantajat and its allies, the consequences were not entirely positive for them. The ensuing presidential elections, with centrist Kyösti Kallio elected, opened the way to a coalition between the Agrarian Union and the Social Democratic Party - the first so-called 'red earth' government in the history of Finland. To prove its trustworthiness as a coalition partner, the Social Democrat Party initiated a mass expulsion of members and MPs in early 1937. Erkki Vala was among them. In the autumn of 1937, Vala was sentenced to six months in prison for publication of foreign newspaper articles criticizing the system of justice in Finland. ${ }^{115}$

The Agrarian Union promoted some of its young stars to ministerial posts, including Urho Kekkonen, who ironically referred to the new government as a 'popular front'. ${ }^{116}$ As Minister of the Interior, Kekkonen repeated his argument that civil rights, the defence of which had galvanized the nation during Finland's struggle to preserve its constitution in the Russian Empire, were a potential threat to independent Finland, because external enemies could abuse them. ${ }^{117}$ In June 1939, Vala found himself in the awkward position of attacking Kekkonen's attempt at outlawing the Fascist party, the Patriotic People's Movement. In parliament, Kekkonen ridiculed Tulenkantajat's appeal to civil rights as another threat to public order. Vala replied that "only those, for whom principle is a foreign word, would find this odd". ${ }^{118}$

\footnotetext{
113 Matti Lackman, Esko Riekki. Jääkärivärväri, Etsivän keskuspoliisin päällikkö, SS-pataljoonan luoja (Suomen Kirjallisuuden Seura 2007) 335-336.

114 Kivimäki (n 105) 105.

115 The sentence was lowered to 30 days on bread and water due to crowded conditions in the prisons. Björne ( $\mathrm{n}$ 72) 248-249; Erkki Vala, 'Tulenkantajat ja tulenkantajat' in Ritva Haavikko (ed), Kirjailijat puhuvat. Tulenkantajat (Suomalaisen Kirjallisuuden Seura 1976) 224-225.

116 Urho Kekkonen, 'Yhtenäinen kansa - itsenäisyytemme vankin turva ja tuki' (1937) 7 Kyntäjä < http://www.doria.fi/handle/10024/11964> accessed 26 February 2018

117 Urho Kekkonen, speech in parliament (5 June 1939) <http://www.doria.fi/handle/10024/8144> accessed 26 February 2018

118 'Demokratian puolustus' (1939) 22 Tulenkantajat 1.
} 


\section{8-1952: The Rights of Refugees, War, And Beyond}

The racist and ideological Gleichschaltung of the Nazi state was met with a certain understanding by those Finnish intellectuals who identified with the idea of national awakening. Even if they did not wish to import Nazism to Finland, some of them saw the purge of 'politically and nationally alien elements' as an understandable and necessary process in Germany. ${ }^{119}$ Some opinionated on the less desirable attributes of Jewish refugees, revealing how they had accepted central parts of antisemitic propaganda, and complained about the financial burden that Germany inflicted on other states by expelling 'undesirables'. ${ }^{120}$ Urho Kekkonen, as Minister of the Interior, was pressured in parliament to guarantee that the Central European refugees would not stay in Finland. ${ }^{121}$

Erkki Vala connected the refugee question to democracy and human rights, expanding the debate on rights to include those who were not citizens of Finland. It was "pointless to speak of established democracy" in a state that did not respect human rights and that did not help strangers in need, Vala argued. Nothing guaranteed that such a state would not violate the rights of its own citizens next. ${ }^{122}$ Civil rights meant a contract between state and individual, but apart from the right that the letter of the law guaranteed, there also existed certain human rights that a 'civilized nation' was not permitted to violate - such as the rights of political refugees. ${ }^{123}$ Vala stressed that the true victims of the arbitrariness of the German state were the German Jews, not the countries that the refugees tried to reach.

Vala's "cascading logic of human rights" resembles the process unleashed after the age of revolutions - upon the promise of the Declaration of the Rights of Man in 1789, one marginalized group after another began to demand those rights: Protestants, Jews, enslaved Blacks, and women. ${ }^{124}$ Vala, as an individual activist, did not represent all the groups that he spoke on behalf of, but he tried to pre-empt a development that he felt threatened Finland, too: a slippery slope toward Fascism.

\footnotetext{
119 Niilo Elo, 'Yliopistouudistus Saksassa' (1934) 5-6 Valvoja-Aika 253-254; Urpo Harva, 'Kolmannen valtakunnan filosofiasta ja tieteestä' (1938) 12 Valvoja-Aika 473.

120 L-s, 'Katsaus ulkomaihin. Puuttuva tasapaino' (1938) 12 Valvoja-Aika 512-515.

121 Urho Kekkonen, 'Vastaus ed. V. Annalan ym. kysymykseen koskeva Keski-Euroopan maista saapuneiden pakolaisten lukumäärä' (21 February 1939) <http://www.doria.fi/handle/10024/8870> accessed 30 July 2018

122 'Majava' (Erkki Vala), 'Entistä ja nykyistä' (1938) 35-36 Tulenkantajat 2.

123 'Majava' (n 122); 'Kansalaisoikeudet paperinpalasina' (1938) 47 Tulenkantajat 1.

${ }^{124}$ Lynn Hunt, Inventing Human Rights - A History (W. W. Norton \& Co. 2008) 175.
} 
In 1939, there were also international tendencies in support of human rights as a cornerstone of a better world order. ${ }^{125}$ However, the rights rhetoric of the Western allies did not find much support in Finland. Väinö Lassila's funeral in April 1939 rang the death-knell of the local League of Human Rights. During the Winter War (1939-1940), the territory and sovereignty of Finland was violated by the USSR, as had happened earlier to other vulnerable states, often to the applause of right-wing Finns who appreciated the imperialist projects of Japan, Italy and Germany. The last issue of Tulenkantajat came out in December 1939. After the peace accords in the spring of 1940, Vala met German and Austrian political refugees in Finland, including Bertolt Brecht. ${ }^{126}$ In autumn 1940, German troops received permission to transit Finland into Norway. Many saw an eventual alliance between Finland and Germany as inevitable. Vala moved to Sweden in August 1941 and settled in Stockholm with an Austrian refugee couple. ${ }^{127}$ His move was related to the political trials against leading anti-war politicians that took place in 1941-42, after Finland had joined the German side in the Continuation War (1941-1944). The trials introduced retroactive punishments for acts that had been judged to be within the realm of civil liberties in peacetime. ${ }^{128}$ Even membership in the League of Human Rights in the 1930s was used as incriminating evidence. ${ }^{129}$ Vala's clandestine political activities caused his arrest and imprisonment in Sweden in 1942. ${ }^{130}$

After the Moscow armistice in 1944, formerly imprisoned or exiled activists returned with the ambition to regain their positions in Finland. Some of them were also expecting nothing less than a fundamental societal change, emboldened by the support that the newly legalized Communist Party of Finland gained at the ballot. Erkki Vala joined the Communist Party in 1945, and in the autumn of 1949, Vala called for a meeting to recreate the League of Human Rights. He served as its chair until he left the Communist Party in 1951. ${ }^{131}$ In the post-war era, the League supported labour activism and strikes; however, it did not gather enough members or funding to cover its expenses and was finally disbanded in 1952.

\footnotetext{
125 Martin Ceadel, 'The Peace Movement and Human Rights' in Pamela Slotte and Miia Halme-Tuomisaari (eds), Revisiting the Origins of Human Rights (Cambridge University Press 2015) 163.

${ }^{126}$ Kalevi Haikara, 'The happiest summer of his life: Brecht in Finland' in Maarten van Dijk (ed), I'm still here =Ich bin noch da (International Brecht Society 1997) 112.

127 National Archive of Finland, EK-Valpo hmp 3608/Vala, Erkki, Ptk. N:o 116/1942.

128 Jukka Lindstedt, 'Valtio näyttää voimansa - Arndt Pekurisen viimeiset päivät syksyllä 1941' (1995) 4 Lakimies 1064.

129 Ensio Hiitonen, Vääryyttä oikeuden valekaavussa (Vapaa Pohjola 1953) 455, 470.

130 Per Meurling, Spionage of sabotage i Sverige (Lindfors 1952) 130, 265-271.

${ }^{131}$ For a study on both periods of the League's activities, see Vuokila (n 78).
} 


\section{Conclusion}

Erkki Vala's evolving conception of human rights can be traced back to liberal and anarchist champions of the civil rights struggle of the pre-independence era, but the decisive impetus of Vala's human rights revival, as well as the strong and long-lasting backlash against it by the authorities, was caused by socialist and communist usage of a universal rights discourse. Vala's liberal education had to be cross-fertilized with the labour movement's revolutionary notion of human rights for him to be able to expand it beyond the nation state. Early post-Civil War liberals like Ensio Hiitonen limited themselves to utilitarian, positivist and even eugenic arguments for the common good. It was Erkki Vala who, with the help of allies like Väinö Lassila, would insist on the primacy of the individual's rights before the state's power in the 1930s.

From the rights of political prisoners, who had merely lost their pre-existing civil rights, to the suffering of the congenitally ill, who were denied rights based on arbitrary prejudice or economic logic, and the refugees and stateless who by no fault of their own had lost their state's protection Vala increasingly defended cases that functioned as litmus tests for democracy and humanity: If these people were not protected against the arbitrariness of the state, what would guarantee the rights of those who still believed themselves to be safe? Focusing on the protection of rights against a hostile state, Vala presaged the concerns of the rights revolution of the coming decade - and no wonder the concerns sprung from the same root, the plight of the stateless and the refugees. Therefore, without claiming any teleological success story for human rights, one may use Vala's individual case as an example of a 'cascading rights discourse' in the vein of Lynn Hunt.

The League of Human Rights in Finland fell victim to bad historical timing. Even though it did its part in preventing the introduction of capital punishment in peacetime legislation, its warnings remained unheeded on the general scale. As the geopolitical situation became increasingly volatile, national protectionism was seen as the only answer in Finland, as in many other European countries. Its failures are perhaps not surprising, considering what it went up against. More impressive and puzzling is perhaps the tenaciousness of certain individuals, such as Erkki Vala, to continue the struggle, despite overwhelming resistance. It is not unthinkable that the struggle became increasingly personal and even a raison d'être as Vala's own life became marked by threats, trials, imprisonment, exile, and the loss of friends and allies to illness and political conflict.

Even though Vala's and Lassila's campaigns in defence of 'human rights' were ultimately unsuccessful, their rhetoric is an early example of a liberal rights discourse where the protection of 
the rights of the individual against the state became a premise for global human rights, contradicting the hegemonic idea of the people as a single organism, the needs of which override the rights of its individual members. Vala tried to combine the role of an intellectual vanguard and a speaker for the collective needs of "young Finland" with the position of a champion of civil liberties. However, the concept of human rights belonged to a shared vocabulary among liberals and openly acting leftists in Finland, which increased the suspicions of the authorities. Considering the massive resistance these actors faced from the state, it seems unfair to hold against them that they failed to "spark the creation of international human rights as an idea or as a movement". ${ }^{132}$ State suspicions and ostracism limited the influence of those liberals who spoke up for human rights at home - and eventually, like a selffulfilling prophecy, pushed them in the welcoming arms of Communism.

132 Moyn (n 3) 38. 